ISSN 1392-3196 / e-ISSN 2335-8947

Zemdirbyste-Agriculture, vol. 106, No. 4 (2019), p. 307-314

DOI $10.13080 / \mathrm{z}-\mathrm{a} .2019 .106 .039$

\title{
A complex assessment of mineral fertilizers with humic substances in an agroecosystem of acid soil
}

\author{
Danutė KARČAUSKIENĖ, Regina REPŠIENĖ, Dalia AMBRAZAITIENE், \\ Ieva MOCKEVIČIENĖ, Gintaras ŠIAUDINIS, Regina SKUODIENE் \\ Lithuanian Research Centre for Agriculture and Forestry, Vèžaičiai Brach \\ Gargždų 29, Vèžaičiai, Lithuania \\ E-mail: danute.karcauskiene@lammc.lt
}

\begin{abstract}
This study aimed to evaluate the impact of total humic extract (THE) and complex mineral fertilizer $\mathrm{N}_{5} \mathrm{P}_{15} \mathrm{~K}_{25}$ enriched with humic substances (HS) $0.5 \%$ on moraine loam soil properties and crop productivity. The field experiment was performed in Western Lithuania $\left(55^{\circ} 43^{\prime} \mathrm{N}, 21^{\circ} 27^{\prime} \mathrm{E}\right)$ at Vèžaičiai Branch of the Lithuanian Research Centre for Agriculture and Forestry in 2015-2017. Experimental object: THE 16.5\%, which contains 13.2\% humic acids, $3.3 \%$ fulvic acids and $5.5 \%$ potassium oxide $\left(\mathrm{K}_{2} \mathrm{O}\right)$, and complex mineral fertilizer $\mathrm{N}_{5} \mathrm{P}_{15} \mathrm{~K}_{25}$ enriched with $\mathrm{HS} 0.5 \%$ consisting of humic and fulvic acids. The soil of the experimental site was moraine loam Bathygleyic Dystric Glossic Retisol. The experiment included the following treatments: 1) unfertilized (control), 2) NPK + THE $20 \mathrm{~L} \mathrm{ha}^{-1}$, 3) NPK traditional, 4) NPK $400 \mathrm{~kg} \mathrm{ha}^{-1}$ with HS $0.5 \%$ and 5) NPK $200 \mathrm{~kg} \mathrm{ha}^{-1}$ with HS $0.5 \%$.

The experimental data indicated that the application of NPK + THE $20 \mathrm{~L} \mathrm{ha}^{-1}$ or complex mineral fertilizers NPK 400 and $200 \mathrm{~kg} \mathrm{ha}^{-1}$ with HS $0.5 \%$ additives tend to mitigate moraine loam soil acidification and to contribute more to the formation of water-stable aggregates in the topsoil compared with NPK traditional. The both rates of mineral NPK fertilizers enriched with HS $0.5 \%$ significantly (by 1.8-2.1 times) increased the content of water-soluble phosphates in the topsoil compared with unfertilized soil. The highest amount of water-extractable organic carbon and the greatest soil biological activity were determined in the soil after incorporation of 400 and $200 \mathrm{~kg} \mathrm{ha}^{-1}$ of mineral fertilizers enriched with HS $0.5 \%$. In terms of crop yield, soil enrichment by mineral fertilizers (400 and $200 \mathrm{~kg} \mathrm{ha}^{-1}$ ) with HS $0.5 \%$ additives and by the NPK + THE $20 \mathrm{~L} \mathrm{ha}^{-1}$ was superior to NPK traditional fertilization.
\end{abstract}

Key words: crop yield, humic substances, soil chemical, biological and physical properties.

\section{Introduction}

Degradation of soil fertility due to use of synthetic agro-inputs is considered as one the most important factors affecting sustainability of agroecosystems. So to achieve sustainable crop production the primary requirement is the maintenance of soil quality and fertility (Biswas et al., 2014). According to many authors (Diacono, Montemurro, 2010; Jokubauskaite et al., 2016), this can be achieved by maintaining organic matter content in the soil. This is especially relevant in ecologically sensitive agro-climatic regions, like Western Lithuania where high amount of rainfall and naturally acid soils are dominating. Various chemical and biological measures are used for improvement the vital functions of these soils. It is well known that lime fertilizers are an effective means for improvement of soil chemical status whereas the organic fertilizers target to increase soil-buffering capacity and promote its better aggregation (Karcauskiene et al., 2018).

Productivity of soils is increased by different ways in the presence of humic materials like humic acids and salts (Peña-Mendez et al., 2005). Humic acids should be mixed into the soil with quickly soluble fertilizers so that nutrients are readily available to plants (Mindari et al., 2019). Different salts of humic substances, such as potassium and calcium humates were used as additives in fertilizers to increase soil fertility. Accumulation level of natural humic acids like potassium humate has shown to reduce the need for commercial fertilizers, because it improves fertilizer efficiency. Humic acids influence the plant growth both directly and indirectly. The indirect effect of humic acid improves physical, chemical and biological conditions of soil and its direct effects are attributed to its metabolic activity in plant growth (Kumar et al, 2013). Humic substances can serve as nitrogen, phosphorus and sulphur reservoirs, improve soil structure, aeration and drainage and increase buffering and exchange capacity (Qian et al., 2015).

The natural process of the formation of humic substances in the soil is very slow; therefore, it is necessary to look for more efficient and faster ways to increase carbon stocks in the soil. Characteristics and content of humic acids vary between sources of organic matter (Mindari et al., 2019). One of the sources of humic

Please use the following format when citing the article:

Karčauskienė D., RepšienėR., Ambrazaitienė D., Mockevičienė I., Skuodienė R., Šiaudinis G. 2019. A complex assessment of mineral fertilizers with humic substances in an agroecosystem of acid soil. Zemdirbyste-Agriculture, 106 (4): $307-314$. DOI 10.13080/z-a.2019.106.039 
acids is the sedimentation layers referred to as leonardite. Leonardite is organic matter that has not reached the state of coal and differs from soft brown coal by its high oxidation degree. Compared to other organic products, leonardite enhances plant growth and soil fertility.

Many researchers (Khaled, Fawy, 2011; Yang et al., 2013) concluded that using humic or fulvic acids together with mineral fertilizers makes an important contribution to soil stability and soil fertility, which leads to exceptional plant growth and nutrient uptake. Physically, humic acids modify the soil structure by regulating the dispersion and flocculation properties of soil. According to Fortun et al. (2006), soil amendment with fulvic and humic acids fractions has a positive effect on soil aggregation. Humic acids are an effective agent to use as a complement to synthetic or organic fertilizers (Khaled, Fawy, 2011) and accelerate plant development by influencing the growth of roots (Peng et al., 2006; Pettit, 2008; Parvan et al., 2013). Selladurai and Purakayastha (2016) reported that humic acids multinutrient liquid fertilizer increased the potato tuber yield by $9.3 \%$ as compared to chemical fertilizers. The study of Qian et al. (2015) showed that the effect of humic acids on crop leaf and root development depends on their molecular weight fractions. Low-molecular weight fractions of humic acids resulted in a significant increase in root length, projective and surface area, while high-molecular weight fractions of humic acids had a tendency to reduce the root length and volume.

Numerous studies (Eidukeviciene et al., 2010; Siaudinis et al., 2017) have shown that the effect of different materials and substances largely depends on the local environment in which it was used. The aim of this study was to evaluate the impact of total humic extract and complex mineral fertilizer $\mathrm{N}_{5} \mathrm{P}_{15} \mathrm{~K}_{25}$ enriched with humic substances $0.5 \%$ on moraine loam soil properties and crop productivity under natural climatic conditions of Western Lithuania.

\section{Materials and methods}

Experimental site and soil description. The field experiment was performed in Western Lithuania $\left(55^{\circ} 43^{\prime} \mathrm{N}, 21^{\circ} 27^{\prime} \mathrm{E}\right)$ at Véžaičiai Branch of the
Lithuanian Research Centre for Agriculture and Forestry in 2015-2017. The soil was naturally acid moraine loam (clay $(<0.002 \mathrm{~mm})-15.0 \%)$ Bathygleyic Dystric Glossic Retisol (WRB, 2014). Before the experiment, the average agrochemical parameters of soil were the following: acidity $\left(\mathrm{pH}_{\mathrm{KCl}}\right)-5.61-5.67$, organic carbon $-0.90-1.15 \%$ (low level), mobile phosphorus $\left(\mathrm{P}_{2} \mathrm{O}_{5}\right)-$ $80-120 \mathrm{mg} \mathrm{kg}^{-1}$ (medium level) and mobile potassium $\left(\mathrm{K}_{2} \mathrm{O}\right)$ - 185-216 mg kg-1 (high level). The experiment was composed of 5 treatments and 4 replications, which were randomly allocated in the experimental plots. The size of each treatment: $12 \times 4=48 \mathrm{~m}^{2}$.

Experimental object. Total humic extract (THE) $16.5 \%\left(165 \mathrm{~g} \mathrm{~L}^{-1}\right)$ contains $13.2 \%$ humic acids (HA), 3.3\% fulvic acids (FA) and 5.5\% potassium oxide (liquid organic product Humistar) and complex mineral fertilizer $\mathrm{N}_{5} \mathrm{P}_{15} \mathrm{~K}_{25}$ enriched with humic substances (HS) $0.5 \%$ consisting of humic and fulvic acid (solid product Humistar).

The characteristics of the tested products. Humistar (liquid and solid) is a product (Tradecorp S. A., Spain) in the manufacturing process derived from American leonardite. Humistar contains HA and FA with a constant ratio (4:1). A high content of HA in the product is intended to increase clay-humus complexes in the soil and promote better soil aggregation. Also the product is responsible for the pseudo-hormonal effect on the lateral and hairy root development.

Experimental design. The experiment included the following treatments: 1) unfertilized (control), 2) NPK + THE $20 \mathrm{~L} \mathrm{ha}^{-1}, 3$ ) NPK traditional, 4) NPK 400 $\mathrm{kg} \mathrm{ha}^{-1}$ with HS $0.5 \%$ and 5) NPK $200 \mathrm{~kg} \mathrm{ha}^{-1}$ with HS $0.5 \%$. Crop fertilization scheme is presented in Table 1 . The experiment was carried out in 2015-2017 in a threefield crop rotation: spring barley (Hordeum vulgare L.), cultivar 'Ula', pea (Pisum sativum L.), cultivar 'Respect' and spring wheat (Triticum aestivum L.), cultivar 'Granary'.

Application of NPK was done on the basis of the largest amount $\left(400 \mathrm{~kg} \mathrm{ha}^{-1}\right)$ of complex mineral fertilizer $\mathrm{N}_{5} \mathrm{P}_{15} \mathrm{~K}_{25}$ enriched with HS $0.5 \%$ in combination with additional applying NPK with rates according to crop requirement for optimal yielding under natural environmental conditions of Western Lithuania.

Table 1. Fertilization scheme of crops in separate treatments*

\begin{tabular}{|c|c|c|}
\hline Spring barley (2015) & Peas (2016) & Spring wheat (2017) \\
\hline $\mathrm{N}_{90} \mathrm{P}_{60} \mathrm{~K}_{100}$ & $\mathrm{~N}_{20} \mathrm{P}_{60} \mathrm{~K}_{100}$ & $\mathrm{~N}_{120} \mathrm{P}_{60} \mathrm{~K}_{100}$ \\
\hline 1. Unfertilized (control) & 1. Unfertilized (control) & 1. Unfertilized (control) \\
\hline 2. $\mathrm{N}_{0} \mathrm{P}_{0} \mathrm{~K}_{0}+$ THE $20 \mathrm{~L} \mathrm{ha}^{-1}$ & 2. $\mathrm{N}_{20} \mathrm{P}_{60} \mathrm{~K}_{100}+$ THE $20 \mathrm{~L} \mathrm{ha}^{-1}$ & 2. $\mathrm{N}_{120} \mathrm{P}_{60} \mathrm{~K}_{100}+$ THE $20 \mathrm{~L} \mathrm{ha}^{-1}$ \\
\hline 3. $\mathrm{N}_{90} \mathrm{P}_{60} \mathrm{~K}_{100}$ traditional & 3. $\mathrm{N}_{20} \mathrm{P}_{60} \mathrm{~K}_{100}$ traditional & 3. $\mathrm{N}_{120} \mathrm{P}_{60} \mathrm{~K}_{100}$ traditional \\
\hline 4. $\mathrm{N}_{5} \mathrm{P}_{15} \mathrm{~K}_{25} 400 \mathrm{~kg} \mathrm{ha}^{-1}$ & 4. $\mathrm{N}_{5} \mathrm{P}_{15} \mathrm{~K}_{25} 400 \mathrm{~kg} \mathrm{ha}^{-1}$ & 4. $\mathrm{N}_{5} \mathrm{P}_{15} \mathrm{~K}_{25} 400 \mathrm{~kg} \mathrm{ha}^{-1}$ \\
\hline with HS $0.5 \%+\mathrm{N}_{70}$ & with HS $0.5 \%+\mathrm{N}_{0}$ & with HS $0.5 \%+\mathrm{N}_{100}$ \\
\hline 5. $\mathrm{N}_{5} \mathrm{P}_{15} \mathrm{~K}_{25} 200 \mathrm{~kg} \mathrm{ha}^{-1}$ & 5. $\mathrm{N}_{5} \mathrm{P}_{15} \mathrm{~K}_{25} 200 \mathrm{~kg} \mathrm{ha}^{-1}$ & 5. $\mathrm{N}_{5} \mathrm{P}_{15} \mathrm{~K}_{25} 200 \mathrm{~kg} \mathrm{ha}^{-1}$ \\
\hline with HS $0.5 \%+\mathrm{N}_{80} \mathrm{P}_{30} \mathrm{~K}_{50}$ & with HS $0.5 \%+\mathrm{N}_{10} \mathrm{P}_{30} \mathrm{~K}_{50}$ & with HS $0.5 \%+\mathrm{N}_{110} \mathrm{P}_{30} \mathrm{~K}_{50}$ \\
\hline
\end{tabular}

Note. ${ }^{*}$ - treatments fertilized with the same specified intensity depending on the plant species; THE - total humic extract, HS humic substances.

For NPK traditional fertilization (treatment 3) and additional application of main nutrients (in other treatments) the following fertilizers were used: ammonium nitrate $\left(\mathrm{NH}_{4} \mathrm{NO}_{3}\right)$, potassium chloride $(\mathrm{KCl})$ and granular single superphosphate. The total humic extract, mineral fertilizers with HS $0.5 \%$ and other mineral fertilizers mixtures were sprayed and dispersed on the soil surface before sowing and inserted into the topsoil at a $4-5 \mathrm{~cm}$ depth by a spring-tine cultivator (Kongskilde, Denmark).
The highest nitrogen $(\mathrm{N})$ rates $\mathrm{N}_{90}$ and $\mathrm{N}_{120}$ were applied over two and three times during spring wheat and spring barley vegetation period. During the three study years the largest amount of humic substances was applied in the soil with annual incorporation of solid complex fertilizer with humic acid $0.5 \%$ additives at a rate of $400 \mathrm{~kg} \mathrm{ha}^{-1}$ (treatment 4) and liquid extract of HS $20 \mathrm{~L} \mathrm{ha}^{-1}$ (treatment 2), and twice lower amount of these humic substances was applied in treatment 5. 
Soil tillage was conventional - deep ploughing, and chemical protection against diseases, insects and weeds was done according to the best local agricultural practice (equally for all treatments). The crop was harvested with a combine harvester Sampo 500 (Sampo Rosenlew, Finland), and the grain yield was calculated to a standard moisture content of $14 \%$ (for barley, peas and wheat).

Sampling and analytical methods employed. Samples for topsoil $(0-20 \mathrm{~cm})$ chemical analyses: $\mathrm{pH}_{\mathrm{KCl}}$, soil organic carbon (SOC) and water-extractable organic carbon (WEOC), were collected once after harvesting every study year. The soil samples for watersoluble phosphates were collected once in the middle of June (2017), two months after fertilizers with humic substances were applied from all treatments with three replicates. Soil analyses were done using the following techniques: $\mathrm{pH}_{\mathrm{KCl}}-1 \mathrm{M} \mathrm{KCl}$ suspension - standard ISO 10390:2005 (Soil quality - Determination of $\mathrm{pH}$ ), SOC - according to Nikitin (1999) by spectrophotometric measurement at a wavelength of $590 \mathrm{~nm}$ using the UVVIS spectrophotometer Cary 50 (Varian) and glucose as a standard after wet combustion, WEOC - by IR-detection method after UV-catalysed persulphate oxidation using the ion chromatograph SKALAR (Skalar Analytical B.V.,
The Netherlands). Phosphate fractions were determined using the procedure of Chang and Jackson (1957), modified by Askinazi et al. (1963).

Samples for topsoil indicator of biological activity expression - carbon dioxide $\left(\mathrm{CO}_{2}\right)$ emission, were collected in 2017 four times (before fertilizer application and one, two and four months after fertilizer application) from all treatments with three replicates. Analyses of soil $\mathrm{CO}_{2}$ emission were done using the titration method (Schinner et al., 1993). For soil structure analysis the samples were collected in the topsoil one and two months after fertilizer application in 2017. The composition of soil aggregates (dry sieving) and their stability in water (wet sieving) were determined by the Savinov method (Вадюнина, Корчагина, 1986)

Meteorological conditions. Success in fertilizer efficiency and spring crop productivity is highly dependent on the amount of precipitation, especially during the spring-summer period. While the abundant rainfall during the autumn-winter period influences more intensive leaching of nutrients and labile carbon compounds. During the three-year experimental period, the weather conditions were rather changeable (Fig. 1).

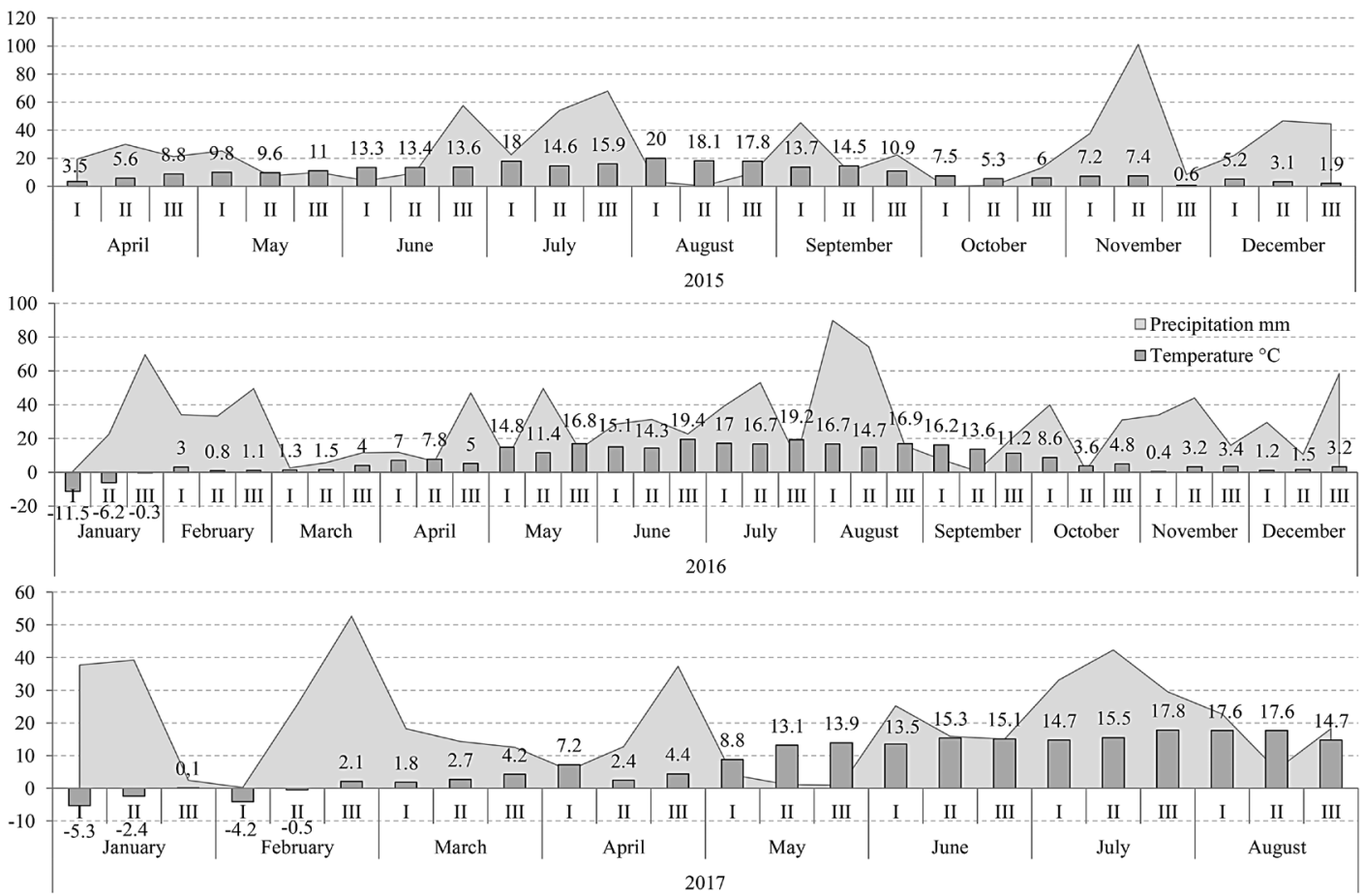

Figure 1. Meteorological conditions during the investigation period 2015-2017 (data of Véžaičiai Meteorological Station, Lithuania)

The meteorological data indicate that the autumn of 2015 was warm and wet. November and December were especially wet. The summer of 2016 was very rainy, especially the first and second ten-day period of August. Monthly precipitation was $179.6 \mathrm{~mm}$, which was twice as high as the standard climate rate $(93.8 \mathrm{~mm})$ of the 1981-2010 period. This may have caused lower efficiency of fertilizers for soil chemical and physical properties due to increased leaching. In 2017, the lack of rainfall in May had a negative effect on spring wheat germination and development. Under these conditions the availability of fertilizers to plants was disturbed.

Statistical analysis. The research data were evaluated using the multi-factor analysis of variance (ANOVA) method. The significance of the differences between the treatments of experiment was evaluated by the one-factor ANOVA method. The significance of the differences between the averages was determined by the least significant difference ( $\operatorname{LSD}_{05}$ ) with $95 \%$ and $99 \%$ probability levels $(p<0.05$ and $p<0.01)$. The relationships among the characteristics were evaluated using the correlation-regression analysis method with the software STAT (Raudonius, 2017).

\section{Results and discussion}

Soil acidity ( $\mathrm{pH}$ ) and water-soluble phosphates. Before the experiment (2015), the soil was slightly acid $\left(\mathrm{pH}_{\mathrm{KCl}} 5.64 \pm 0.03\right)$. The different rates and forms of fertilizers did not influence the soil $\mathrm{pH}$ variation in 2015 and 2016 (Fig. 2). 


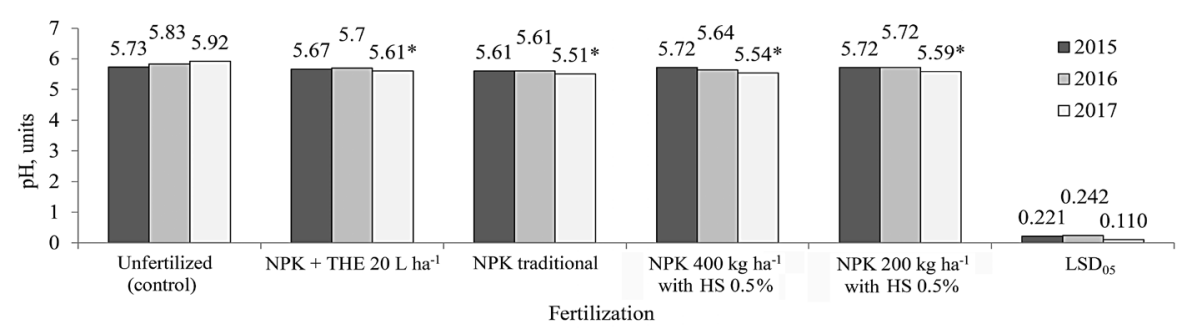

* - significant at 0.05 probability level; THE - total humic extract, HS - humic substances

Figure 2. Topsoil acidity (pH) as affected by mineral fertilizers with humic substances, 2015-2017

Meanwhile, in the year 2017, after the complex mineral fertilizers with humic substances additives had been incorporated annually for three years and quantity of fertilizers in individual treatments tended to increase, the tendency of soil $\mathrm{pH}$ decrease was determined. The $\mathrm{pH}$ of differently fertilized soil was by $0.31-0.41$ units lower compared to unfertilized soil. Ali and Mindari (2016) study showed that the incorporation of humic acids into the soil helps to regulate the soil's chemical status and neutralize its acidity. Summarizing the study data, it can be concluded that the amount of HS $0.5 \%$ as an additive in complex mineral fertilizer that was incorporated into the individual soil treatments during the three years' period cannot be characterized as a measure to neutralize soil acidity. The least change in soil $\mathrm{pH}$ was determined when the THE $20 \mathrm{~L} \mathrm{ha}^{-1}$ was applied into the soil. Incorporation of traditional mineral fertilizers caused the fastest soil acidification. In summary, it can be affirmed that the application of liquid humic extract or complex mineral fertilizer (NPK 200 and $400 \mathrm{~kg} \mathrm{~h}^{-1}$ ) enriched with HS $0.5 \%$ additives had a lesser effect on soil $\mathrm{pH}$ decrease than traditional mineral fertilizers.

Phosphorus (P) is an essential macronutrient for plant growth. Low content of phosphates in the plat root environment inhibits root development. Humic acids affect the transformation of phosphorus compounds. Wang et al. (2007) reported that the application of humic acids from lignite in an alkaline soils solubilized phosphorus from phosphates and this slowly contributed to the soil's available phosphorus budget. Humic acids are especially beneficial in freeing up nutrients in the soil so that they are made available to the plants as needed. If an aluminium molecule is bound with one of phosphorus, humic acids increases availability of the phosphorus for the plants (Khaled, Fawy, 2011).

The data of this study showed that the changes in water-soluble phosphates depended on fertilization type (Fig. 3). Compared with unfertilized soil, the application of complex mineral fertilizer (NPK 400 and $200 \mathrm{~kg} \mathrm{ha}^{-1}$ ) enriched with HS $0.5 \%$ significantly (by $1.8-2.1$ times) increased the content of water-soluble phosphates in the topsoil and made phosphorus more available to the crops. The moraine loam soil treated with complex mineral fertilizers enriched with HS 0.5\% accumulated 2.6-2.9 times more water-soluble phosphates than traditionally fertilized soil.

Qualitative changes in soil organic carbon (SOC). The past decades have raised the need for comprehensive studies on the soil properties and environmental factors controlling SOC quantity and

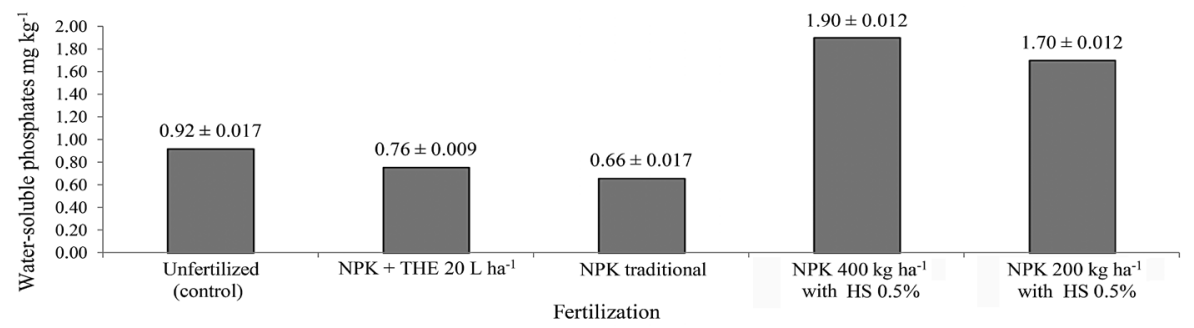

Mean values \pm standard deviation; THE - total humic extract, HS - humic substances

Figure 3. Water-soluble phosphates content in the topsoil as affected by mineral fertilizers with humic substances in the spring wheat crop, 2017

quality. SOC accumulation can be enhanced by positive land management techniques, such as green manure and farmyard manure application. The application of organic amendments to soil has beneficial effects, mainly because such amendments supply organic matter and their nutritive elements to the soil-plant system (Powlson et al., 2012). There was not found any statistically significant effect of fertilizers with humic substances additives on the quantity of SOC in the soil during all study years (Fig. 4).

SOC amount in fertilized treatments varied from $1.07 \%$ to $1.26 \%$. In 2016 , SOC content was the highest: in the fertilized plots it was approximately by 0.1-0.2 percentage points higher compared to that in the other study years.

Water-extractable organic carbon (WEOC), being a small but highly sensitive fraction of organic matter in the soil, may provide a mechanism as well as prediction opportunities for soil fertility, conservation, sustainability and protection against degradation. It was revealed that the different fertilizer rates had an effect on WEOC amount in the soil during all three study years. As it is shown in Figure 5, fertilization with NPK $200 \mathrm{~kg} \mathrm{ha}^{-1}$ with HS $0.5 \%$ resulted in the lowest amount of WEOC $\left(0.178 \mathrm{~g} \mathrm{~kg}^{-1}\right)$ in soil in 2015 .

Various mechanisms have been suggested to explain this phenomenon, such as increased organic matter solubility, increased microbial activity, an increase in the production of soluble molecules due to the decrease in biologically toxic $\mathrm{Al}$ at higher $\mathrm{pH}$, and the displacement of the previously adsorbed WEOC by other mobilised anions (Filep, Rékási, 2011). There is also a possibility that not only the amount of SOC but also the $\mathrm{N}$ status influence WEOC amount in the soil for either biological or physicochemical reasons. Furthermore, $\mathrm{N}$ limited sites may respond differently to sites where $\mathrm{N}$ availability is already high. Possible effects as a result of altered enzyme activities include changes in both production of WEOC and mineralization of WEOC (Zak et al., 2011). The highest 


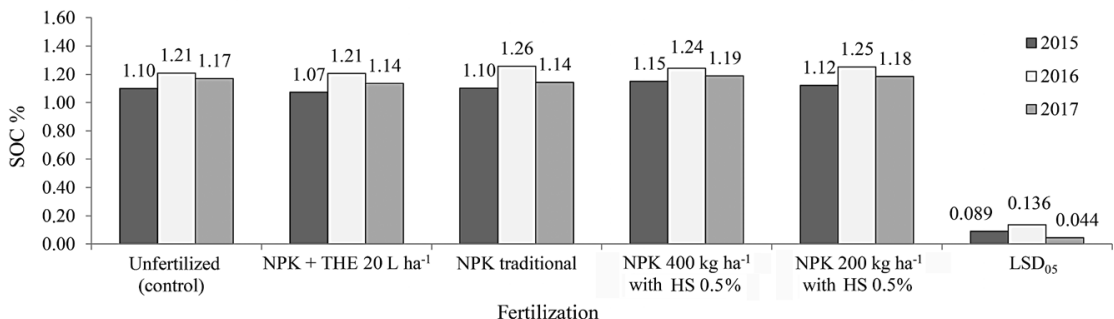

THE - total humic extract, HS - humic substances

Figure 4. Soil organic carbon (SOC) content in the topsoil as affected by mineral fertilizers with humic substances, 2015-2017

amount of WEOC $\left(0.19 \mathrm{~g} \mathrm{~kg}^{-1}\right)$ was determined in the soil after the incorporation of NPK $400 \mathrm{~kg} \mathrm{ha}^{-1}$ with HS $0.5 \%$ with humic acid $0.5 \%$ additives.

According to these data, amendment of fertilizers with HS $0.5 \%$ additives at the highest rates, stimulated the formation of early stage humic acids in the soil, which could be incorporated in stable humic acids compounds and in such a way increased stability of humic acids in the soil. During the second year (2016), the tendency of the WEOC decreasing was established compared to the first year (2015) of study. The content of WEOC slightly decreased in all study treatments, excluding unfertilized (control) treatment and treatment where the NPK with $400 \mathrm{~kg} \mathrm{ha}^{-1}$ with HS $0.5 \%$ were incorporated (Fig. 5). This immediate increase is generally attributed to the presence of soluble materials in the amendments, leading to alterations in the formation of complexes between organic ligands and metals and the soil organic matter sequestration (Yu et al., 2012; Wen et al., 2014). The lowest amount of WEOC was established in the soil where the NPK traditional and NPK $200 \mathrm{~kg} \mathrm{ha}^{-1}$ with HS $0.5 \%$ were applied. It was 0.16 and $0.161 \mathrm{~g} \mathrm{~kg}^{-1}$, respectively. The amount of WEOC in these treatments was approximately by $0.018 \mathrm{~g} \mathrm{~kg}^{-1}$ lower compared to the first year (2015) of study. In 2017, WEOC analysis revealed, that the lowest amount of WEOC $\left(0.149 \mathrm{~g} \mathrm{~kg}^{-1}\right)$ was in the soil plots, which were applied by NPK + THE $20 \mathrm{~L} \mathrm{ha}^{-1}$. This could be related to the increase of organic matter solubility and microbial activity that promoted the mineralization processes in the soil (Fig. 5).

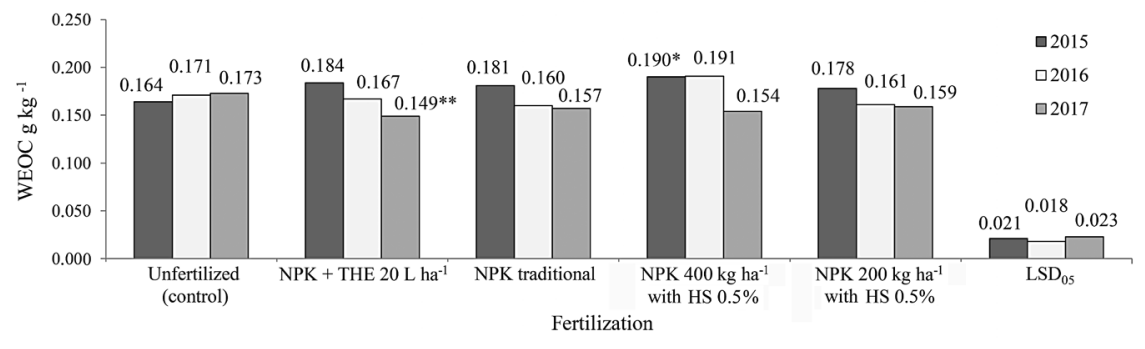

* and ** - significant at 0.05 and 0.01 probability levels; THE - total humic extract, HS - humic substances

Figure 5. Water-extractable organic carbon (WEOC) content in the topsoil as affected by mineral fertilizers with humic substances, 2015-2017

Soil biological activity. The influence of complex mineral fertilizers containing humic substances additives on soil biological activity was assessed by $\mathrm{CO}_{2}$ emission from the soil, based on the assertion that increase of microorganism activity is accompanied by higher $\mathrm{CO}_{2}$ emission from the soil (McFarland et al., 2013). Fertilizer efficiency for microbiological activity was evaluated in the final third year of the study (2017) by taking soil samples from the field experiment conducted for three years, when fertilizers were applied every year to the same treatment plots.

The investigation carried out at the beginning of 2017, before the spring fertilization (4 May, 2017), showed unequal conditions for microorganism activity that developed during two years of study with different fertilization (Table 2). In fertilized soils, the biological activity was higher due to the more favourable nutrient content compared with the control treatment.

A significant increase in the microorganism activity was found in the soil, which had been applied with complex mineral fertilizer enriched with HS $0.5 \%$ additives and NPK traditional (supplemented by ammonium nitrate $\left(\mathrm{NH}_{4} \mathrm{NO}_{3}\right)$, potassium chloride $(\mathrm{KCl})$ and single granular superphosphate), compared with the control treatment. The biological activity in the soil treated by mineral NPK fertilizers with THE
$20 \mathrm{~L} \mathrm{ha}^{-1}$ was greater than in the control treatment due to more favourable soil moisture and nutrient conditions one month after fertilizer application. A further study showed that after one month of incorporation of NPK + THE $20 \mathrm{~L} \mathrm{ha}^{-1}$ and at the beginning of dry season, $\mathrm{CO}_{2}$ emission decreased in all study treatments, except for the treatment were NPK $200 \mathrm{~kg} \mathrm{ha}^{-1}$ with HS $0.5 \%$ were applied

After two months the biological activity intensified in all study treatments. It was influenced by the increase of soil moisture. Particularly during this period, the increased efficiency of NPK + THE $20 \mathrm{~L} \mathrm{ha}^{-1}$ for $\mathrm{CO}_{2}$ emission was determined, but there were no significant differences compared to other treatments.

At the end of spring wheat vegetation, that is four months after fertilizer application, the amount of $\mathrm{CO}$, emitted from the soil decreased almost twice in all study treatments, but significantly higher amount of $\mathrm{CO}_{2}$ $\left(0.027 \mathrm{mg} \mathrm{g}^{-1}\right.$ absolutely dry soil day $\left.{ }^{-1}\right)$ at this study period was determined in the soil fertilized by NPK $200 \mathrm{~kg} \mathrm{ha}^{-1}$ with HS $0.5 \%$ compared to other treatments. A similar trend was observed when assessing the change of $\mathrm{CO}_{2}$ emission rate throughout the vegetation period of 2017 : incorporation of NPK 400 and $200 \mathrm{~kg} \mathrm{ha}^{-1}$ with HS $0.5 \%$ increased the biological activity of soil microorganisms. This is related to SOC and WEOC fraction in the soil. 
Table 2. The biological activity in the topsoil as affected by mineral fertilizers with humic substances, 2017

\begin{tabular}{|c|c|c|c|c|c|}
\hline \multirow[b]{2}{*}{ Treatment } & \multicolumn{5}{|c|}{ Carbon dioxide $\left(\mathrm{CO}_{2}\right)$ emission, $\mathrm{mg} \mathrm{g}^{-1}$ absolutely dry soil day ${ }^{-1}$} \\
\hline & $\begin{array}{c}04052017 \\
\text { before } \\
\text { fertilizers } \\
\text { application }\end{array}$ & $\begin{array}{c}05062017 \\
\text { one month } \\
\text { after fertilizers } \\
\text { application }\end{array}$ & $\begin{array}{c}04072017 \\
\text { two months } \\
\text { after fertilizers } \\
\text { application }\end{array}$ & $\begin{array}{c}04082017 \\
\text { four months } \\
\text { after fertilizers } \\
\text { application }\end{array}$ & Average \\
\hline 1. Unfertilized (control) & 0.029 & 0.027 & 0.047 & 0.021 & 0.031 \\
\hline 2. NPK + THE $20 \mathrm{~L} \mathrm{ha}^{-1}$ & 0.032 & 0.028 & 0.047 & 0.016 & 0.031 \\
\hline 3. NPK traditional & 0.034 & 0.022 & 0.044 & 0.021 & 0.030 \\
\hline 4. NPK $400 \mathrm{~kg} \mathrm{ha}^{-1}$ with HS $0.5 \%$ & 0.038 & 0.031 & 0.041 & 0.021 & 0.033 \\
\hline 5. NPK $200 \mathrm{~kg} \mathrm{ha}^{-1}$ with HS $0.5 \%$ & 0.034 & 0.035 & 0.043 & 0.027 & 0.035 \\
\hline $\mathrm{LSD}_{05}$ & 0.004 & 0.006 & 0.010 & 0.004 & 0.004 \\
\hline
\end{tabular}

THE - total humic extract, HS - humic substances

The correlation-regression analysis showed a moderate correlation $(r=0.545, P<0.005)$ between SOC and $\mathrm{CO}_{2}$ emissions from the soil. WEOC was significantly negatively correlated $(r=-0.559, P<0.001)$ with $\mathrm{CO}_{2}$ emission. As it is shown in the literature, the humic acids of different origins influence the growth of soil bacterial cultures and bacteria isolated from digestive tracts of earthworms; however, the mechanism of action of humic substances has not yet been sufficiently investigated and humic substances are considered to have auxin and auxin-like activity (Tikhonov et al., 2010).
Soil aggregate stability is a key indicator of soil quality. Changes in aggregate stability may serve as an early indicator of soil recovery or soil degradation. Various indicators are used for evaluation of soil structure, but in this work the amount of water-stable aggregates $>0.25$ $\mathrm{mm}$ were used. The increasing amount of these aggregates indicates that the soil physical quality is recovered. The obtained results revealed that one month after fertilization, the amount of water-stable aggregates varied in a narrow range from $38 \%$ in unfertilized plot to $45 \%$ in the plot applied by NPK $400 \mathrm{~kg} \mathrm{ha}^{-1}$ with HS $0.5 \%$ (Fig. 6).

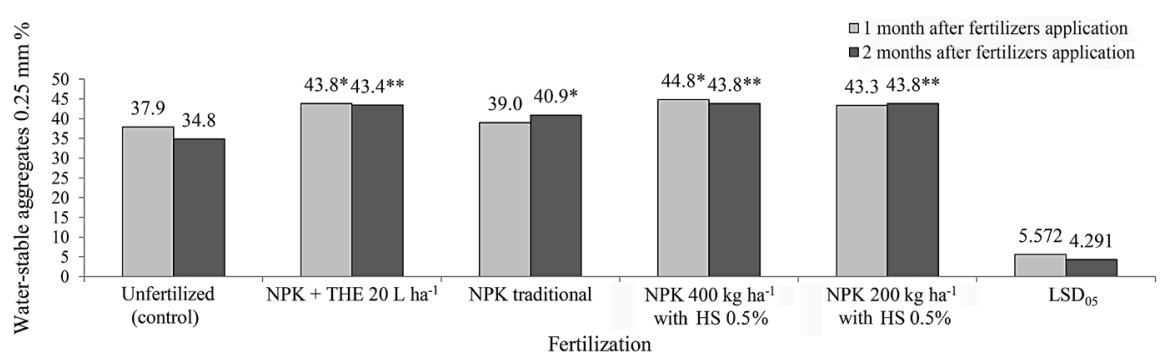

* and ** - significant at 0.05 and 0.01 probability levels; THE - total humic extract, HS - humic substances

Figure 6. The amount of water-stable aggregates $(>0.25 \mathrm{~mm})$ in the topsoil as affected by mineral fertilizers with humic substances in the spring wheat crop, 2017

Two months after application of fertilizers with humic substances, the amount of water-stable aggregates $>0.25 \mathrm{~mm}$ in the topsoil was $8.6-9.0$ percentage units more than in unfertilized control treatment. Among fertilized treatments, the lowest amount (39-40\%) of water-stable aggregates during the study period was determined in the soil with traditional mineral fertilization. Therefore, it can be affirmed that fertilization by NPK + THE $20 \mathrm{~L}$ $\mathrm{ha}^{-1}$ and NPK 400 or $200 \mathrm{~kg} \mathrm{ha}^{-1}$ with HS $0.5 \%$ additives liquid extract of humic acid and solid NPK with humic acid $0.5 \%$ additives had a more significant contribution to water-stable aggregates formation in the moraine sandy loam soil compared with traditional mineral fertilization.

Crop grain yield. Unsuitable soil conditions for the plant development and yielding generally arise from the lack of organic matter content in the soil. To solve this problem, humic substances have to be given to the soil to improve the crop yield (Khaled, Fawy, 2011). Khan et al. (2018) reported in alkaline calcareous sandy loam soils a wheat grain yield increase of $11-21 \%$ over control by application fertilizers with humic acids extract derived from plant and coal materials. The presented proposition is supported by the data of this study. In 2016-2017, the addition of HS $0.5 \%$ to moraine loam soil with complex mineral fertilizers 400 and $200 \mathrm{~kg} \mathrm{ha}^{-1}$ or humic extract $20 \mathrm{~L} \mathrm{ha}^{-1}$ significantly increased the yield of peas and spring wheat by $23-34 \%$ and $74-76 \%$, respectively, compared to unfertilized treatment (Fig. 7).

In terms of the crop yield, soil enrichment by complex mineral fertilizers (400 and $200 \mathrm{~kg} \mathrm{ha}^{-1}$ ) with HS $0.5 \%$ additives and humic extract $20 \mathrm{~L} \mathrm{ha}^{-1}$ was superior to NPK traditional fertilization. As a result

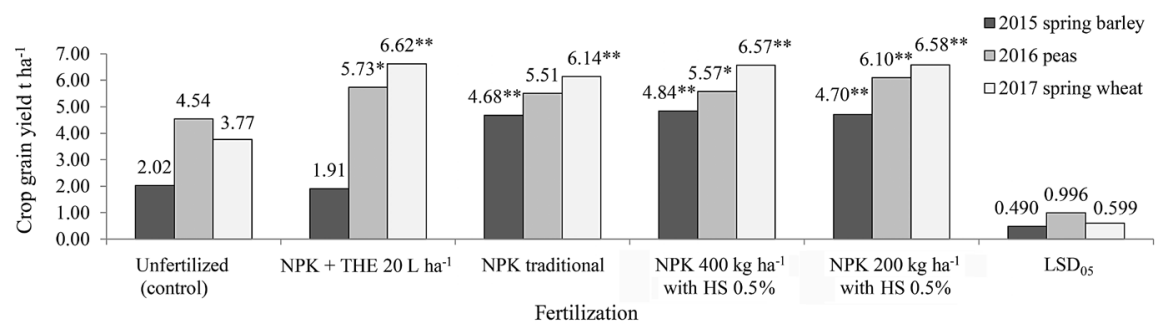

* and ** - significant at 0.05 and 0.01 probability levels; THE - total humic extract, HS - humic substances

Figure 7. Crop grain yield as affected by mineral fertilizers with humic substances, 2015-2017 
of this fertilization, pea yield was $1-11 \%$ higher and spring wheat yield was 7-8\% higher compared to NPK traditional fertilization. In the first year of study (2015) in the soil treated by NPK 400 and $200 \mathrm{~kg} \mathrm{ha}^{-1}$ with HS $0.5 \%$ additives the spring barley grain yield was $2.3-2.4$ times higher than in the unfertilized treatment. Meanwhile, in the soil where humic extract $20 \mathrm{~L} \mathrm{ha}^{-1}$ was sprayed (treatment 2) and NPK were not applied that study year, the yield of spring barley was lower than in the unfertilized control treatment. The obtained data support the positive effect of mineral fertilizers with humic substances on crop yield, especially on peas and spring wheat.

\section{Conclusions}

1. The application of NPK + total humic extract (THE) $20 \mathrm{~L} \mathrm{ha}^{-1}$ or complex mineral fertilizers NPK 400 and $200 \mathrm{~kg} \mathrm{ha}^{-1}$ with humic substances (HS) $0.5 \%$ additives tended to mitigate moraine loam soil acidification compared with traditional mineral fertilization under natural Western Lithuania climatic conditions.

2. The both rates (400 and $200 \mathrm{~kg} \mathrm{ha}^{-1}$ ) of complex mineral NPK fertilizers enriched with HS $0.5 \%$ significantly (by 1.8-2.1 times) increased the content of water-soluble phosphates in the topsoil and made phosphorus more available to the crops compared with the unfertilized soil.

3. There was not found any statistically significant effect of fertilizers with humic substances additives on the quantity of soil organic carbon (SOC) in the soil, while the highest amount $\left(0.19 \mathrm{~g} \mathrm{~kg}^{-1}\right)$ of waterextractable organic carbon (WEOC) was determined in the soil after the incorporation of $400 \mathrm{~kg} \mathrm{ha}^{-1}$ of complex mineral NPK fertilizers enriched with HS $0.5 \%$.

4. Average data show that, compared to other treatments, the application of complex mineral fertilizers NPK 200 and $400 \mathrm{~kg} \mathrm{ha}^{-1}$ with HS $0.5 \%$ additives had the greatest positive effect on the biological activity of the moraine loam soil.

5. Fertilization with THE $20 \mathrm{~L} \mathrm{ha}^{-1}$ and complex mineral fertilizers NPK 400 and $200 \mathrm{~kg} \mathrm{ha}^{-1}$ with HS $0.5 \%$ additives tended to contribute more to the formation of water-stable aggregates in the moraine loam soil compared with traditional mineral fertilization.

6. In terms of the crop yield, soil enrichment by complex mineral fertilizers NPK 400 and $200 \mathrm{~kg} \mathrm{ha}^{-1}$ with HS $0.5 \%$ additives and THE $20 \mathrm{~L} \mathrm{ha}^{-1}$ was superior to NPK traditional fertilization in 2016-2017. This fertilization with humic substances resulted in $1-11 \%$ and $7-8 \%$ higher yield of peas and spring wheat, respectively compared with NPK traditional fertilization. Meanwhile, application of mineral fertilizers NPK 400 and $200 \mathrm{~kg} \mathrm{ha}^{-1}$ with HS $0.5 \%$ additives spring barley yield increased by $0.43 \%$ and $3.42 \%$, respectively, compared with NPK traditional fertilization, and the yield was 2.2-2.3 times higher than that in the control treatment in 2015.

\section{Acknowledgments}

The paper presents research findings obtained through the long-term research programme "Productivity and sustainability of agricultural and forest soils" implemented by the Lithuanian Research Centre for Agriculture and Forestry. This research work was also supported by the company "Tradecorp Benelux SA" (Belgium).

Received 18032019

Accepted 13082019

\section{References}

1. Ali M., Mindari W. 2016. Effect of humic acid on soil chemical and physical characteristics of embankment. MATEC Web of Conferences, 58: 6.

https://doi.org/10.1051/matecconf/20165801028

2. Askinazi D. L., Ginzburg K. E., Lebedeva L. S. 1963. Mineral phosphorus compounds in soil and methods of its determination. Pochvovedenije, 5: 27-29 (in Russian)

3. Biswas S., Ali N. M., Goswami R., Chakraborty S. 2014. Soil health sustainability and organic farming: a review. Journal of Food, Agriculture and Environment, $12(3-4): 237-243$

4. Chang S. C. Jackson M. L. 1957. Fractionation of soil phosphorus. Soil Science, 84: 133-144. https://doi.org/10.1097/00010694-195708000-00005

5. Diacono M., Montemurro F. 2010. Long-term effects of organic amendments on soil fertility. A review. Agronomy for Sustainable Development, 30: 401-422. https://doi.org/10.1051/agro/2009040

6. Eidukeviciene M., Volungevicius J., Marcinkonis S., Tripolskaja L., Karcauskiene D., Fullen M. A., Booth C. A. 2010. Interdisciplinary analysis of soil acidification hazard and its legacy effects in Lithuania. Natural Hazards and Earth System Sciences, 10 (7): 1477-1485. https://doi.org/10.5194/nhess-10-1477-2010

7. Filep T., Rékási M. 2011. Factors controlling dissolved organic carbon (DOC), dissolved organic nitrogen (DON) and $\mathrm{DOC} / \mathrm{DON}$ ratio in arable soils based on a dataset from Hungary. Geoderma, 162: 312-318. https://doi.org/10.1016/j. geoderma. 2011.03.002

8. Fortun A., Benayas J., Fortun C. 2006. The effects of fulvic and humic acids on soil aggregation: a micromorphological study. European Journal of Soil Science, 41 (4): 563-572. https://doi.org/10.1111/j.1365-2389.1990.tb00226.x

9. Jokubauskaite I., Karcauskiene D., Slepetiene A., Repsiene R., Amaleviciute K. 2016. Effect of different fertilization modes on soil organic carbon sequestration in acid soils. Acta Agriculturae Scandinavica, Section B: Soil and Plant Science, 66 (8): 653-663. https://doi.org/10.1080/09064710.2016.1181200

10. Karcauskiene D., Repsiene R., Ambrazaitiene D., Skuodiene R., Jokubauskaite I. 2018. Soil pH control, ecological and agronomic assessment in agroecosystem. Soil $\mathrm{pH}$ for nutrient availability and crop performance. IntechOpen, p. 47-71. https://doi.org/10.5772/intechopen.75764

11. Khaled H., Fawy H. A. 2011. Effect of different levels of humic acids on the nutrient content, plant growth and soil properties under conditions of salinity. Soil and Water Resources. 6 (1): 21-29. https://doi.org/10.17221/4/2010-SWR

12. Khan R. U., Khan M. Z., Khan A., Saba S., Hussain F., Jan I. U. 2018. Effect of humic acid on growth and crop nutrient status of wheat on two different soils. Journal of Plant Nutrition, 41: 453-460. https://doi.org/10.1080/01904167.2017.1385807

13. Kumar D., Singh A. P., Raha P., Rakshit A., Singh C. M., Kishor P. 2013. Potassium humate: a potential soil conditioner and plant growth promoter. International Journal of Agriculture, Environment and Biotechnology, 6 (3): 441-446. https://doi.org/10.5958/j.2230-732X.6.3.015

14. McFarland J. W., Waldrop M. O., Haw M. 2013. Extreme $\mathrm{CO}_{2}$ disturbance and the resilience of soil microbial communities. Soil Biology and Biochemistry, 65: 274-286. https://doi.org/10.1016/j.soilbio.2013.04.019

15. Mindari W., Sasongko P. E., Kusuma Z., Syekhfani, Aini M. 2019. Efficiency of various sources and doses of humic acid on physical and chemical properties of saline soil and growth and yield of rice. AIP Conference Proceedings, 2018 (1): 030001. https://doi.org/10.1063/1.5061854

16. Nikitin B. A. 1999. Methods for soil humus determination. Agrochemistry, 3 (2): 156-158 (in Russian).

17. Parvan L., Dumitru M., Sirbu C., Cioroianu T. 2013. Fertilizer with humic substances. Romanian Agricultural Research, 30: 205-212.

18. Peña-Mendez E. M., Havel J., Potocka J. 2005. Humus substances-compounds of still unknown structure: applications in agriculture, industry, environment and biomedicine. Journal of Applied Biomedicine, 3: 12-24. https://doi.org/10.32725/jab.2005.002 
19. Peng Z., Bi S., Men M., Xue S. 2006. Effects of humic acid compound fertilizer on the application rates of rape and its physiological index. Journal of Agricultural University of Hebei, 29: 15-18.

20. Pettit R. E. 2008. Organic matter, humus, humate, humic acid, fulvic acid and humin: their importance in soil fertility and plant health. https://humates.com/pdf/ ORGANICMATTERPettit.pdf

21. Powlson D. S., Bhogal A., Chambers B. J., Coleman K., Macdonald A. J. 2012. The potential to increase soi carbon stocks through reduced tillage or organic material additions in England and Wales: a case study. Agriculture, Ecosystems and Environment, 146: 23-33. https://doi.org/10.1016/j.agee.2011.10.004

22. Raudonius S. 2017. Application of statistics in plant and crop research: important issues. Zemdirbyste-Agriculture, 104 (4): 377-382. https://doi.org/10.13080/z-a.2017.104.048

23. Qian S., Ding W., Li Y., Liu G., Sun I., Ding Q. 2015. Characterization of humic acids derived from leonardite using a solid-state MMR spectroscopy and effects of humic acids on growth and nutrient uptake of snap been. Chemical Speciation and Bioavailability, 27 (4): 156-161. https://doi.org/10.1080/09542299.2015.1118361

24. Schinner F. et al. (eds). 1993. Bodenbiologische Arbeitsmethoden. Springer, 640 p. (in German). https://doi.org/10.1007/978-3-642-77936-7

25. Selladurai R., Purakayastha T. J. 2016. Effect of humic acid multinutrient fertilizers on yield and nutrient use efficiency of potato. Journal of Plant Nutrition, 39: 949-956. https://doi.org/10.1080/01904167.2015.1109106

26. Siaudinis G., Arlauskienė A., Repšienè R., Sarūnaitė L., Skuodiene R. 2017. The effect of bacterial application on the productivity of faba bean (Vicia faba L.) And its mixture with spring wheat (Triticum aestivum L.) under two agroclimatic conditions in Lithuania. Applied Ecology and Environmental Research, 15 (4): 2011-2021. https://doi.org/10.15666/aeer/1504 20112021
27. Tikhonov V. V., Yakushev A. V., Zavgorodnyaya Yu. A., Byrov B. A., DeminV. V. 2010. Effects of humic acids on the growth of bacteria. Eurasian Soil Science, 43 (3): 305-313. https://doi.org/10.1134/S1064229310030087

28. Wang X. J., Wang Z. Q., Li S. G. 2007. The effect of humic acids on the availability of phosphorus fertilizers in alkaline soils. Soil Use and Management, 11 (2): 99-102. https://doi.org/10.1111/j.1475-2743.1995.tb00504.x

29. Wen Y., Li H., Xiao J., Wang C., Shen Q., Ran W., He X., Zhou Q., Yu G. 2014. Insights into complexation of dissolved organic matter and Al(III) and nanominerals formation in soils under contrasting fertilizations using two-dimensional correlation spectroscopy and high resolution-transmission electron microscopy techniques. Chemosphere, 111: 441-449. https://doi.org/10.1016/j.chemosphere.2014.03.078

30. WRB. 2014. World reference base for soil resources. World Soil Resources Reports No. 106. FAO, p. 187-189.

31. Yang S., Zhang Z., Cong L., Wang X., Shi S. 2013. Effect of fulvic acid on the phosphorus availability in acid soil. Journal of Soil Science and Plant Nutrition, 13 (3). https://doi.org/10.4067/S0718-95162013005000041

32. Yu G. H., Wu M. J., Wei G. R., Luo Y. H., Ran W., Zhang J. C., Shen Q. R. 2012. Binding of organic ligands with $\mathrm{Al}(\mathrm{III})$ in dissolved organic matter from soil: implications for soil organic carbon storage. Environmental Science and Technology, 46 (11): 6102-6109. https://doi.org/10.1021/es3002212

33. Zak D. R., Pregitzer K. S., Burton A. J., Edwards I. P., Kellner H. 2011. Microbial responses to a changing environment: implications for the future functioning of terrestrial ecosystems. Fungal Ecology, 4: 386-395. https://doi.org/10.1016/j.funeco.2011.04.001

34. Вадюнина А. Ф., Корчагина 3. А. 1986. Методы исследования физических свойств почвы. Москва, Россия, 416 c. (in Russian).

ISSN 1392-3196 / e-ISSN 2335-8947

Zemdirbyste-Agriculture, vol. 106, No. 4 (2019), p. 307-314

DOI $10.13080 /$ z-a.2019.106.039

\title{
Mineralinių trąšų su huminių medžiagų priedu kompleksinis ivertinimas agroekosistemoje rūgščiame dirvožemyje
}

\author{
D. Karčauskienė, R. Repšienė, D. Ambrazaitienė, I. Mockevičienė, R. Skuodienė, G. Šiaudinis \\ Lietuvos agrarinių ir miškų mokslų centro Vėžaičių filialas
}

\section{Santrauka}

Tradiciškai intensyviai ūkininkaujant agroekosistemoje su rūgščiais dirvožemiais laipsniškai mažeja organinès anglies kiekis. Sprendžiant šią problemą svarbus huminių medžiagų naudojimas. Tyrimo tikslas - kompleksiškai įvertinti huminių medžiagų ekstrakto ir kompleksinių mineralinių trąšų $\mathrm{N}_{5} \mathrm{P}_{15} \mathrm{~K}_{25}$ su huminių medžiagų $0,5 \%$ priedu įtaką moreninio priemolio dirvožemio savybėms ir sejjomainos augalų derliui. Lauko eksperimentas buvo vykdytas 2015-2017 m. Vakaru Lietuvoje, Lietuvos agrarinių ir mišku mokslų centro Véžaičiu filiale $\left(55^{\circ} 43^{\prime}\right.$ $\mathrm{N}, 21^{\circ} 27^{\prime}$ E). Tyrimo objektas - huminių medžiagų 16,5\% ekstraktas, sudarytas iš $13,2 \%$ huminių rūgščių, $3,3 \%$ fulvinių rūgščiu bei $5,5 \%$ kalio oksido $\left(\mathrm{K}_{2} \mathrm{O}\right)$ ir kompleksinès mineralinès trąšos $\mathrm{N}_{5} \mathrm{P}_{15} \mathrm{~K}_{25}$, papildytos $0,5 \%$ huminių medžiagu priedu, sudarytu iš huminių ir fulvinių rūgščių. Tyrimo dirvožemis - giliau glejiškas nepasotintasis balkšvažemis. Tyrimas atliktas pagal schemą: 1) netręšta (kontrolinis variantas), 2) NPK + huminiu rūgščių ekstraktas $20 \mathrm{~L} \mathrm{ha}^{-1}$, 3) tradicinis tręšimas NPK trąšomis, 4) NPK $400 \mathrm{~kg} \mathrm{ha}^{-1}$ su huminių medžiagų $0,5 \%$ priedu ir 5) NPK $200 \mathrm{~kg} \mathrm{ha}^{-1}$ su huminių medžiagų $0,5 \%$ priedu.

Eksperimento duomenys parodè, kad tręšimas mineralinèmis trąšomis kartu su huminių medžiagų $20 \mathrm{~L} \mathrm{ha}^{-1}$ ekstraktu arba kompleksinèmis mineralinėmis NPK 400 ir $200 \mathrm{~kg} \mathrm{ha}^{-1}$ trąšomis su huminių medžiagų 0,5 \% priedu mažiau rūgština dirvožemị ir labiau skatina vandenyje patvarių dirvožemio trupinèliu susidarymą nei tradicinis tręšimas mineralinėmis NPK trąšomis. Palyginus su netręštu dirvožemiu, abi normos (200 ir $\left.400 \mathrm{~kg} \mathrm{ha}^{-1}\right)$ kompleksinių mineraliniu NPK trašu su huminiu medžiagu $0,5 \%$ priedu iš esmès $(1,8-2,1$ karto) padidino vandenyje tirpių fosfatų kiekị dirvožemyje. Didžiausias kiekis vandenyje tirpios organinès anglies ir didžiausias dirvožemio biologinis aktyvumas nustatytas dirvožemiuose, tręštuose 400 ir $200 \mathrm{~kg} \mathrm{ha}^{-1}$ mineralinių trąšų, papildytų huminių medžiagų $0,5 \%$ priedu. Sèjomainos augalų derliaus atžvilgiu tręšimas mineralinėmis NPK trąšomis su huminių medžiagų $20 \mathrm{~L} \mathrm{ha}^{-1}$ ekstraktu arba kompleksinėmis mineralinėmis NPK 400 ir $200 \mathrm{~kg} \mathrm{ha}^{-1}$ trąšomis su huminių medžiagų $0,5 \%$ priedu buvo pranašesnis už tradicinį tręšimą mineralinėmis trąšomis. 